\title{
Failure of a Massive Single Oral Dose of Vitamin A to Prevent Deficiency
}

\author{
SHEILA M. PEREIRA and ALMAS BEGUM \\ From the Nutrition Research Unit, Christian Medical College and Hospital, Vellore-4, Tamil Nadu, India
}

\begin{abstract}
Pereira, Sheila M., and Begum, Almas (1971). Archives of Disease in Childhood, 46, 525. Failure of a massive single oral dose of Vitamin $A$ to prevent deficiency. Preschool children maintained on low and moderate carotene diets were given a single oral dose of 50,000 $\mu$ g vitamin A palmitate.

On the low carotene diet, xerosis was observed in 8 weeks' time in the control group of children, and in 10 weeks' time in the children given the load of vitamin A. Statistical differences in serum vitamin $A$ values between the groups were not of significance after 18 weeks.

Children on a moderate carotene diet did not benefit from the loading dose of vitamin $\mathrm{A}$.
\end{abstract}

Milk and other animal foods, because of their relatively high cost, are not eaten by the majority of children in South India, who depend almost entirely on carotene sources for their daily requirements of vitamin A. Though readily available, green leafy vegetables are not eaten in adequate amounts: for example, in a village typical of the area, the children's food provided an average of just $180 \mu \mathrm{g}$ (300 IU) $\beta$-carotene a day (Sundararaj et al., 1969). The common occurrence of deficiency signs, affecting $5-11 \%$ of the children examined during surveys assessing nutritional status, is therefore not unexpected (Gopalan, 1957; Rao et al., 1960; Swaminathan, Apte, and Someswara Rao, 1960; Someswara Rao, Taskar, and Ramanathan, 1954).

A massive dose of vitamin A $(100,000 \mu \mathrm{g})$ has been reported as maintaining adequate serum levels for periods of up to 2 years (Susheela, 1969), and able to prevent deficiency when given to preschool children (Swaminathan, Susheela, and Thimmayamma, 1970). In both these reports, however, no controls were included, so that it is difficult to eliminate the influences of seasonal variation of dietary intake, and the results cannot be attributed solely to the ingestion of a large dose of vitamin A.

In a field study, a similar oral dose was accompanied by signs of vitamin $A$ toxicity in $8 \%$ of the children to whom it was given (Nutrition Research Laboratories, Hyderabad, Annual Report 1965-66).

Received 17 March 1971.
It was therefore suggested that half the dose, given at 6-monthly intervals, would eradicate deficiency.

The present study was undertaken to observe the effect of $50,000 \mu \mathrm{g}$ vitamin A palmitate in preventing deficiency in preschool children.

\section{Materials and Methods}

Forty-seven children between the ages of 2 and 6 years, resident in an orphanage, took part in the study. The children were in apparent good health and none showed clinical signs of vitamin A deficiency; that is, they showed neither dryness and non-wettability of the bulbar conjunctiva by tears (xerosis), nor accumulations of foamy or greasy material on the roughened bulbar conjunctiva exposed in the palpebral fissure adjoining the limbus (Bitot's spots), nor haziness and dryness of the cornea resulting in a ground glass appearance (keratomalacia).

For 9 months before the present study, the children were on a diet that provided $2 \mathrm{~g}$ vegetable protein and $90 \mathrm{cal} / \mathrm{kg}$ per day, and $620-650 \mu \mathrm{g} \beta$-carotene per day. For the 2 weeks preceding the study the children were on a diet free of vitamin $A$ and carotene.

Blood was drawn from the children after an overnight fast and serum vitamin $A$ estimated. The children were allocated to 4 groups so that the mean and range of the serum vitamin A values were comparable between the groups.

Half an hour before their noon meal, the children in groups I and II were each given 50,000 $\mu \mathrm{g}$ vitamin A palmitate in arachis oil, orally. The children in groups III and IV were given an equal volume of arachis oil.

The children in groups I and III (i.e. one of the groups given the vitamin A and one that was not) were main- 
tained on a low carotene diet providing $120 \mu \mathrm{g} \beta$ carotene per day. The children in groups II and IV were given green leafy vegetables to provide $900 \mu \mathrm{g}$ $\beta$-carotene per day.

Blood was drawn after an overnight fast from all subjects at intervals of two weeks and the serum vitamin A estimated by the trifluoroacetic acid method (Neeld and Pearson, 1963) modified by Roels, Trout, and Begum (1968). Correction was applied for $\beta$-carotene interference when required.

The children were examined at intervals and the clinical signs of vitamin A deficiency recorded. Children who developed xerosis or Bitot's spots were kept under close observation till the termination of the study at 18 weeks.

\section{Results}

One child from group IV was in hospital for several weeks for the investigation and treatment of chronic diarrhoea and was excluded from the study. The results pertain to the 12 children each in groups I and III and the 11 children in groups II and IV who completed the study.

The average serum values of the children before and during the 18 weeks after the oral dose of vitamin $A$ are given in the Table.

The average serum values of the children kept on the low carotene diet (groups I and III) are given in Fig. 1. The average serum values of the children in group I (given vitamin A) rose and were maintained for several weeks following the load, as compared with those of the children in group III. By the 10th week, statistical differences between the average values of the 2 groups were not of significance. There were differences of some statistical significance between the values of the 2 groups at the 12th, 14th, and 16th weeks $(P<$ $0.025,0.05$, and 0.005 , respectively). By the 18 th week, serum values in both groups were below $15 \mu \mathrm{g} / 100 \mathrm{ml}$ a level at which serious clinical deficiencies have been encountered (Pereira, Begum and Dumm, 1966). The difference in average values in groups I and III were not of statistical significance at this point.

The average serum values of the children on moderate carotene intakes (groups II and IV) are depicted in Fig. 2. The children in group II were given the vitamin $A$, resulting in significantly higher serum values compared to the children in group IV for 2 weeks after the dose $(P=0.001)$. There was fluctuation in the average values of the 2 groups in the weeks following. However, the values of both groups stayed around or above 20 $\mu \mathrm{g} / 100 \mathrm{ml}$. during the period of study.

The first signs of vitamin A deficiency appeared 8 weeks after the start of the study. Two children in group III, given the low carotene diet without the load of vitamin A, showed xerosis and Bitot's spots. One child in group IV on the moderate carotene diet also showed a Bitot's spot. In all

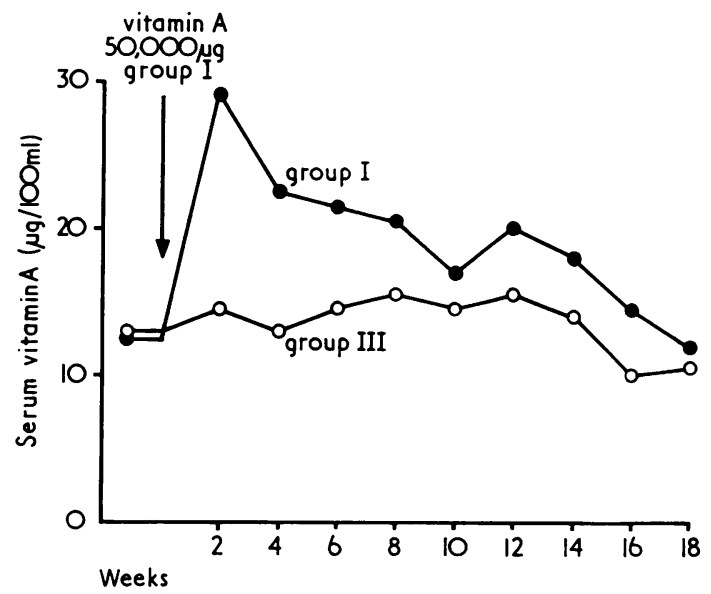

Fig. 1.-The average serum values of vitamin $A$ of the children on the low carotene diet (120 $\mu$ g carotene/day). The children in group I were given 50,000 $\mu \mathrm{g}$ vitamin $A$ palmitate as a single oral dose.

TABLE

Serum Values of Vitamin $A$ of Children in 4 Groups

\begin{tabular}{|c|c|c|c|c|c|c|c|c|c|c|c|c|}
\hline & Dose of & $\beta$-carotene & 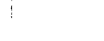 & & Serum & Vitamin & Values & $\mu g / 100$ & 1 (mean & \pm 1 SD) & & \\
\hline & $\begin{array}{c}\text { Given } \\
(\mu \mathbf{g})\end{array}$ & $\begin{array}{c}\text { Diet } \\
(\mu \mathrm{g} / \text { day })\end{array}$ & $\begin{array}{l}\text { Initial } \\
\text { values }\end{array}$ & $\begin{array}{c}2 \\
\text { wk }\end{array}$ & $\begin{array}{c}4 \\
w k\end{array}$ & $\underset{\text { wk }}{6}$ & $\begin{array}{c}8 \\
\text { wk }\end{array}$ & $\begin{array}{c}10 \\
\text { wk }\end{array}$ & $\begin{array}{c}12 \\
\text { wk }\end{array}$ & $\begin{array}{l}14 \\
\text { wk }\end{array}$ & $\begin{array}{l}16 \\
w k\end{array}$ & $\begin{array}{c}18 \\
w k\end{array}$ \\
\hline $\begin{array}{l}\text { Group I: } \\
12 \text { children } \\
\text { Group II: } \\
11 \text { children } \\
\text { Group III: } \\
12 \text { children } \\
\text { Group IV: } \\
11 \text { children }\end{array}$ & $\begin{array}{r}50,000 \\
50,000 \\
0\end{array}$ & $\begin{array}{l}120 \\
900 \\
120 \\
900\end{array}$ & $\begin{array}{r}12 \cdot 5 \\
\pm 3 \cdot 6 \\
12 \cdot 2 \\
\pm 2 \cdot 7 \\
12 \cdot 7 \\
\pm 3 \cdot 2 \\
13 \cdot 2 \\
\pm 3 \cdot 1\end{array}$ & $\begin{array}{r}29 \cdot 2 \\
\pm 5 \cdot 7 \\
26 \cdot 3 \\
\pm 7 \cdot 1 \\
14 \cdot 7 \\
\pm 3 \cdot 3 \\
21 \cdot 4 \\
\pm 4 \cdot 5\end{array}$ & $\begin{array}{r}22 \cdot 6 \\
\pm 5 \cdot 9 \\
21 \cdot 3 \\
\pm 4 \cdot 2 \\
13 \cdot 3 \\
\pm 2 \cdot 8 \\
23 \cdot 2 \\
\pm 7 \cdot 5\end{array}$ & $\begin{array}{r}21 \cdot 6 \\
\pm 2 \cdot 4 \\
27 \cdot 9 \\
\pm 4 \cdot 9 \\
14 \cdot 8 \\
\pm 2 \cdot 6 \\
26 \cdot 3 \\
\pm 7 \cdot 8\end{array}$ & $\begin{array}{r}20 \cdot 5 \\
\pm 5 \cdot 7 \\
20 \cdot 7 \\
\pm 6 \cdot 7 \\
15 \cdot 3 \\
\pm 3 \cdot 9 \\
20 \cdot 8 \\
\pm 5 \cdot 6\end{array}$ & $\begin{array}{r}17 \cdot 1 \\
\pm 3 \cdot 6 \\
23 \cdot 1 \\
\pm 7 \cdot 8 \\
14 \cdot 7 \\
\pm 4 \cdot 5 \\
21 \cdot 4 \\
\pm 5 \cdot 1\end{array}$ & $\begin{array}{r}20 \cdot 1 \\
\pm 5 \cdot 0 \\
24 \cdot 9 \\
\pm 7 \cdot 1 \\
15 \cdot 4 \\
\pm 2 \cdot 9 \\
22 \cdot 0 \\
\pm 5 \cdot 1\end{array}$ & $\begin{array}{r}17 \cdot 9 \\
\pm 4 \cdot 4 \\
25 \cdot 2 \\
\pm 8 \cdot 3 \\
14 \cdot 0 \\
\pm 3 \cdot 1 \\
19 \cdot 5 \\
\pm 5 \cdot 0\end{array}$ & $\begin{array}{r}14 \cdot 3 \\
\pm 3 \cdot 3 \\
20 \cdot 0 \\
\pm 5 \cdot 0 \\
10 \cdot 0 \\
\pm 2 \cdot 6 \\
20 \cdot 2 \\
\pm 6 \cdot 9\end{array}$ & $\begin{array}{r}12 \cdot 1 \\
\pm 3 \cdot 0 \\
24 \cdot 3 \\
\pm 7 \cdot 3 \\
10 \cdot 7 \\
\pm 2 \cdot 3 \\
19 \cdot 6 \\
\pm 5 \cdot 7\end{array}$ \\
\hline
\end{tabular}




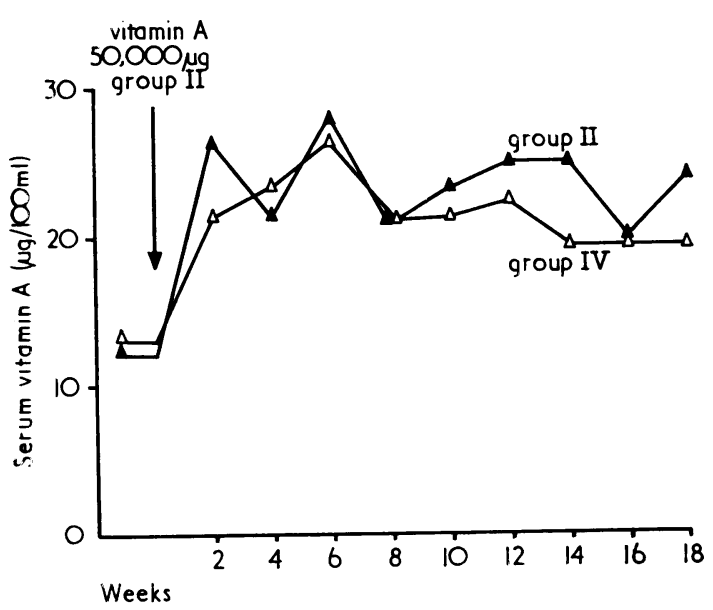

FIG. 2.-The average serum values of vitamin $A$ of the children on the moderate carotene diet (900 $\mu \mathrm{g}$ carotene) day). The children in group II were given 50,000 $\mu \mathrm{g}$ vitamin $A$ palmitate as a single oral dose.

3 subjects the deficiency signs persisted until the end of the study. By the 10th week, two children in group I, given the loading dose of vitamin A and a low carotene diet, developed xerosis and Bitot's spots which persisted until the end of the study. At 16 weeks, a third child in group III showed xerosis of the conjunctiva. None of the children in group II, given the dose of vitamin A and maintained on the moderate carotene diet, showed clinical evidence of deficiency.

The study was terminated at 18 weeks by which time 6 children of the 46 had xerosis or Bitot's spots; 2 in group I, 3 in group III, and 1 in group IV.

\section{Discussion}

Despite a loading dose of $50,000 \mu \mathrm{g}$ vitamin A, 2 of the 12 children maintained on a low carotene diet showed conjunctival xerosis at 10 weeks, and all but $3 \mathrm{had}$ serum levels below $15 \mu \mathrm{g} / 100 \mathrm{ml}$ at 18 weeks.
The load had no clinical or biochemical advantage for children on a moderate carotene diet.

The findings are in accordance with previous experience, when a load of $100,000 \mu \mathrm{g}$ vitamin A was unable to maintain adequate serum levels beyond 15 to 19 weeks when given to depleted children (Pereira and Begum, 1969).

We thank Mrs. Sheila Jones for planning the diets of the children and Mr. G. Jesudian and Mr. Sampathkumar Mathews for the statistical analyses of the data.

This study was supported by Agreement No. 114302 PL 480 Funds from the National Institutes of Health, United States Public Health Service.

\section{REFERENCES}

Gopalan, C. (1957). Malnutrition among infants and young children in India. Fournal of Tropical Pediatrics and African Child Health, 3, 3.

Neeld, J. B., Jr., and Pearson, W. N. (1963). Macro- and micromethods for the determination of serum vitamin A using trifluoroacetic acid. Fournal of Nutrition, 79, 454.

Nutrition Research Laboratories, Hyderabad (1966). Annual Report (1965-1966), p. 64. Indian Council of Medical Research, New Delhi.

Pereira, S. M., and Begum, A. (1969). Prevention of vitamin A deficiency. American fournal of Clinical Nutrition, 22, 858.

Pereira, S. M., Begum, A., and Dumm, M. E. (1966). Vitamin A deficiency in kwashiorkor. American fournal of Clinical Nutrition, 19, 182.

Rao, B. R. H., Klontz, C. E., Benjamin, V., Rao, P. S. S., Begum, A., and Dumm, M. E. (1960). Nutrition status survey of the rural population in Sholavaram. Fournal of the Indian Medical Association, 35, 259.

Roels, O. A. Trout, M., and Begum, A. (1968). The Vitamins. Vol. 6. Academic Press, New York.

Someswara Rao, K., Taskar, A. D., and Ramanathan, M. K. (1954). Nutrition and haemoglobin surveys in children in Nilgiris District. Indian fournal of Medical Research, 42, 55.

Sundararaj, R., Begum, A., Jesudian, G., and Pereira, S. M. (1969). Seasonal variation in the diets of pre-school children in a village (North Arcot District). II. Intake of vitamins and minerals. Indian fournal of Medical Research, 57, 375.

Susheela, T. P. (1969). Studies on serum vitamin A levels after a single massive oral dose. Indian fournal of Medical Research, 57, 2147.

Swaminathan, M. C., Apte, S. V., and Someswara Rao, S. (1960). Nutrition of the people of Ankola Taluk. Indian Fournal of Medical Research, 48, 762.

Swaminathan, M. C., Susheela, T. P., and Thimmayamma, B. V. S. (1970). Field prophylactic trial with a single annual oral massive dose of vitamin A. American fournal of Clinical Nutrition, 23, 119.

Correspondence to Dr. Sheila M. Pereira, Nutrition Research Unit, Christian Medical College and Hospital, Vellore-4, Tamil Nadu, India. 